\title{
Alternative Control of Plant Pathogen Fungi Through Ethanolic Extracts of Avocado Seeds (Persea Americana Mill.)
}

\author{
Miriã Cristina Pereira Fagundes ${ }^{1 *}$, Adelson Francisco de Oliveira ${ }^{2}$, Vicente Luiz de \\ Carvalho $^{2}$, José Darlan Ramos ${ }^{3}$, Verônica Andrade dos Santos ${ }^{3}$, José Carlos Moraes \\ Rufini $^{1}$ \\ 1 Universidade Federal de São João del-Rei, Sete Lagoas, Minas Gerais, Brazil ${ }^{2}$ Empresa de Pesquisa \\ Agropecuária de Minas Gerais, Belo Horizonte, Minas Gerais, Brazil ${ }^{3}$ Universidade Federal de Lavras, Lavras, \\ Minas Gerais, Brazil.
}

\begin{abstract}
The aim of this study was to evaluate the antifungal action of ethanolic extracts of avocado seeds, by conducting two experiments in the laboratory of plant pathology of EPAMIG SUL/Lavras, MG, Brazil, in a completely randomized design with three replicates. The first consisted of the following treatments ('Breda' 3\%, 'Breda' 2\%, 'Margarida' $3 \%$, 'Margarida' 2\%, Control, and Ethanol) testing its inhibitory effect on two fungal species (Colletotrichum gloeosporioides and Monilinia fructicola) and the second consisted of different concentrations of extracts (0\%, $0.25 \%, 0.50 \%, 0.75 \%, 1.0 \%, 1.5 \%$, and $2.0 \%$ ) on the fungus $F$ fructicola. The evaluations were performed at three times (7, 14, and 21 days of incubation) by measurements of the mycelial diameter using a digital caliper. The data were submitted to analysis of variance and the averages were compared by Scott-Knott test at 5\% probability. The results demonstrated the positive potential of the ethanolic extracts of avocado seed on the mycelial development of fungi M. fructicola and C. gloeosporioides during the evaluated days.
\end{abstract}

Keywords: antifungal activity, Colletotrichum gloeosporioides, Monilinia fructicola, postharvest

\footnotetext{
* Author for correspondence: miria.agro@yahoo.com.br
} 


\section{INTRODUCTION}

Fruit-growing is one of the most important segments of Brazilian agriculture, being Brazil the third largest producer of fresh fruit, surpassed only by China and India. Nevertheless, Brazil's share of world fruit exports is still incipient, accounting for less than $3 \%$ of its production ${ }^{1}$. One of the main limiting factors to the increase in the export of fresh fruits is postharvest losses caused by pests, nematodes, physiological disturbances, mechanical damage and diseases caused by plant pathogen microorganisms, including fungi.

As an example of these fungi, Colletotrichum gloeosporioides and Monilinia fructicola are plant pathogen fungi involved in a large number of postharvest diseases, being developed primarily in the fruit storage stage ${ }^{2,3}$.

C. gloeosporioides is responsible for anthracnose, a disease that attacks temperate, subtropical and tropical fruit trees. Moreover, the genus Colletotrichum is responsible for other diseases in a wide variety of crops, including cereals, legumes and vegetables ${ }^{4}$. According to Phoulivong et al. ${ }^{5}$, the importance of this pathogen goes beyond postharvest losses, since it allows a market's behavioral variation, leading to socioeconomic changes.

The pathogen $M$. fructicola is the causative agent of brown rot, the main postharvest disease of seed rosacea (peach, plum and nectarine) ${ }^{6}$.

Traditionally, the control of postharvest diseases of fruits is based on the use of synthetic chemicals, especially fungicides. However, due to the several problems caused by them, such as harmful effects on human health and the environment, besides problems with plant pathogen resistance, has driven the search for more efficient controls and less aggressive to society and the environment ${ }^{7,8}$.

Reports on the use of biofungicides extracted from plants are common over the centuries, these are rich in compounds as essential oils, terpenoids and alkaloids, besides lectins, polypeptides and phenolic substances and polyphenols, which are subdivided into single phenols, phenolic acids, quinines ${ }^{9}$.

In the case of the avocado Persea americana Mill., the species contains specialized idioblast cells that are almost completely filled with alkaloid-containing oil, sesquiterpene hydroperoxides and possibly other terpenes ${ }^{10}$, being the most active constituent known as "persina" ${ }^{11}$. Moreover, this substance has many biological activities described by Rodriguez-Saona et al. ${ }^{12}$ and belongs to the group of acetogenins, which are biologically active substances, restricted to the families of Annonaceae and Lauraceae ${ }^{13}$.

Several studies using extracts and essential oils of different plant species have been carried out in several countries ${ }^{14-19}$, showing its potential in control of plant pathogens through its direct fungitoxic action, acting as inhibitor of mycelial growth, formation of appressorium and the fungal spore germination, besides the effect on plant by the ability to induce the accumulation of phytoalexins in resistance mechanisms ${ }^{20}$.

Based on the above, this study aimed to evaluate the antifungal activity of ethanol extracts of avocado seeds (Persea americana Mill.) in the control of mycelial growth in vitro of fungi Colletotrichum gloesporioides and Monilinia fructicola.

\section{MATERIAL AND METHODS}

The study was developed in the Laboratory of Plant Pathology of EPAMIG SUL/Lavras - MG, Brazil, from March to August 2015 and was constituted by in vitro tests. 


\section{Obtaining the isolates}

For tests involving ethanol extract, isolates of Colletotrichum gloeosporioides and Monilinia fructicola from apple (Malus domestica L.) and peach (Prunus persica (L.) Batsch) were used, respectively.

Apple fruits with symptoms of anthracnose and peach with symptoms of brown rot were washed in running water and subsequently disinfested in $1 \%$ sodium hypochlorite solution for $1 \mathrm{~min}$, then transferred to a vessel containing distilled water. The excess moisture was withdrawn with sterile filter paper. After drying the fruits, a wet chamber was made at $25^{\circ} \mathrm{C}$ for the development of fungi present in the fruit for later identification (seven days). The fragments containing the fungal structures of interest were plated in PDA (Potato-Dextrose-Agar) culture medium under aseptic conditions and incubated in a growth chamber (BOD) at $25 \pm 2{ }^{\circ} \mathrm{C}$ for seven days. The identification of the fungi was done through taxonomy based on morphological aspects. After identification of fungi were stored in mycology collection of the Laboratory of Plant Pathology EPAMIG.

At the moment of the assay assembly, the fungi were repixed in PDA medium and conditioned in BOD for seven days to obtain an active culture, which were used for mycelial growth inhibition tests.

\section{Obtaining the ethanolic extract}

The extracts were obtained from two commercial cultivars of avocado (Persea americana Mill.) 'Breda' and 'Margarida'.

The seeds of fruits from the cultivars constituted the plant material used to accomplishment of the extracts. Ten seeds of each cultivar were collected from an avocado producing farm in São Sebastião do Paraíso, Minas Gerais. After the collection, they were placed for drying in natural environment until reaching 10 to $15 \%$ of humidity.

After drying, the seeds were crushed to the mill powder. A total of $20 \mathrm{~g}$ of the dried material each cultivar was weighed, which was immersed in $100 \mathrm{ml}$ of $70 \%$ ethanol $(\mathrm{v} / \mathrm{v})$, separately. The solutions were stored in glass bottles, closed and wrapped in aluminum foil so that there was no interference of light. This condition was maintained for 30 days and the solutions were stirred three times a day during this time. Finally, these solutions were filtered using a funnel with a layer of hydrophilized gauze. From the filtration, $100 \mathrm{ml}$ of the extracts were obtained which were kept in a light-free environment until the test was carried out. The filtrate was added to the potato-dextrose-agar (PDA) culture medium in order to obtain the different concentrations of the extracts to be evaluated. The dilutions used in the two tests started from the initial extract and were made according to the pharmaceutical method of maceration ${ }^{21}$.

\section{Verification of the antifungal activity of ethanolic extracts}

The experiment consisted of two tests: First test was conducted with high concentrations as a starting point to define the fungitoxic activity of the extracts on fungi growth. In this first trial the tests were composed of the following treatments: (Breda 3\%, Breda 2\%, Margarida 3\%, Margarida 2\%, Control and Alcohol), and two species of fungi ( $C$. gloeosporioides and $M$. fructicola). The evaluations were performed at three times (7, 14 and 21 days of incubation) by measurements of the mycelial diameter, using a digital caliper. All tests were performed in vitro, in a laminar flow hood with all sterilized equipment, to maintain a complete asepsis condition. 
After the results of the first test, $M$. fructicola fungus that had high percent inhibition with the $2 \%$ and $3 \%$ extracts composed the second assay. For this, smaller concentrations were used: alcohol extract $(0 \%, 0.25 \%, 0.50 \%, 1.0 \%, 1.5 \%$, and $2.0 \%)$ were used for the two avocado cultivars. The evaluations were performed at three times $(7,14$, and 21 days of incubation) by measurements of the mycelial diameter using a digital caliper, being calculated the inhibition percentage by the following formula adapted from Edington et al. ${ }^{22}: \mathrm{I}=[(\mathrm{GFC}-\mathrm{GFT}) / \mathrm{GFC}] \times \mathrm{100}$, Where: $\mathrm{I}=$ inhibition percentage; GFC = growth of fungus in the control; GFT = growth of the fungus in the treatment. All the experiments were conducted in a randomized complete block design with three replicates. Each experimental plot was represented by a $9 \mathrm{~cm}$ Petri dish containing $15 \mathrm{ml}$ PDA and $0.3 \mathrm{~cm}$ diameter discs containing fragments of the pathogens. The data were submitted to analysis of variance, and the averages were compared by the Skott-Knott test at 5\% error probability, using the SISVAR software ${ }^{23}$.

\section{RESULTS AND DISCUSSION}

The results of the effect of ethanol extracts on the growth of in vitro fungi Colletotrichum gloeosporioides and Monilinia fructicola are presented in Table 1. The analysis of variance indicated differences in the antifungal activity of plant extracts on the pathogens used in the study.

Table 1. Percent inhibition (\%) of Monilinia fructicola and Colletotrichum gloesporioides under the influence of different ethanol extracts at different concentrations.

\begin{tabular}{cccc}
\hline & \multicolumn{3}{c}{ Days } \\
\cline { 2 - 4 } Ethanolic extracts & 7 & 14 & 21 \\
\hline Breda 2\% & $77.43 \mathrm{a}$ & $89.09 \mathrm{a}$ & $91.82 \mathrm{a}$ \\
Breda 3\% & $79.52 \mathrm{a}$ & $90.86 \mathrm{a}$ & $93.56 \mathrm{a}$ \\
Margarida 2\% & $79.52 \mathrm{a}$ & $90.86 \mathrm{a}$ & $89.80 \mathrm{a}$ \\
Margarida 3\% & $79.52 \mathrm{a}$ & $90.86 \mathrm{a}$ & $93.56 \mathrm{a}$ \\
Alcohol & $37.92 \mathrm{~b}$ & $8.45 \mathrm{~b}$ & $0.00 \mathrm{~b}$ \\
\hline Control & $0.00 \mathrm{c}$ & $0.00 \mathrm{~b}$ & 11.89 \\
\hline CV (\%) & 40.49 & 31.88 & $8.96 \mathrm{a}$ \\
& & Colletotrichum gloesporioides & $2.54 \mathrm{a}$ \\
\hline Breda 2\% & $46.64 \mathrm{~b}$ & $10.87 \mathrm{a}$ & $4.71 \mathrm{a}$ \\
Breda 3\% & $58.41 \mathrm{a}$ & $17.75 \mathrm{a}$ & $10.14 \mathrm{a}$ \\
Margarida 2\% & $51.23 \mathrm{~b}$ & $15.94 \mathrm{a}$ & $3.98 \mathrm{a}$ \\
Margarida 3\% & $59.37 \mathrm{a}$ & $21.01 \mathrm{a}$ & $0.00 \mathrm{a}$ \\
\hline Alcohol & $19.80 \mathrm{c}$ & $3.62 \mathrm{~b}$ & 4.69 \\
\hline Control & $0.00 \mathrm{~d}$ & $0.00 \mathrm{~b}$ & 6.55 \\
\hline
\end{tabular}

Averages followed by the same letter on the columns do not differ among themselves by Scott-Knott test at $5 \%$ probability.

For M. fructícola, it was observed that regardless of the used extract, all showed antifungal activity on colony growth with increased efficiency throughout the evaluation period, with the highest inhibition percentage at 21 days, with an average of $93.56 \%$ for the extracts of $3 \%$ for both evaluated cultivars. These results show that ethanol has efficiency to extract the antifungal substances for this pathogen.

However, for C. gloeosporioides, the efficiency was only observed up to the 14th day of evaluation, with the higher average percentages of inhibition in the first seven days $(58.41 \%$ and $59.37 \%)$ for the extracts from the cultivar 
Breda and Margarida, respectively, both at concentrations of 3\%. Similar results were found by Pansera et al. ${ }^{24}$, where the essential oil of Eucalyptus globulus inhibited mycelial growth on the third day at concentrations of $0.15 \%$ and $0.20 \%$. However, from the seventh day, there was pathogen growth at all tested concentrations. These results differed from the results found by Silva et al. ${ }^{25}$, which obtained $100 \%$ inhibition percentage testing clove extract (Syzygium aromaticum), whereas the Nim extract (Azadirachta indica L.) inhibited $20.22 \%$ in a concentration of $3 \%$.

From the 14th day of evaluation, there was a reduction in the inhibition capacity of $C$. gloeosporioides, regardless of the cultivar used to obtain the extract, which can be attributed to the evaporation of chemical constituents with inhibitory activity of extracts as well as to the instability of the same in the presence of abiotic factors such as light, heat, air and water inside the Petri dishes.

However, despite the results, both extracts proved to be much more efficient in the control of the pathogen causing brown rot on peach, being necessary to identify an ideal concentration for the control. Therefore, significant interactions were observed among the concentrations and the ethanol extracts in the mycelial growth of the pathogen at seven days (Fig. 1).

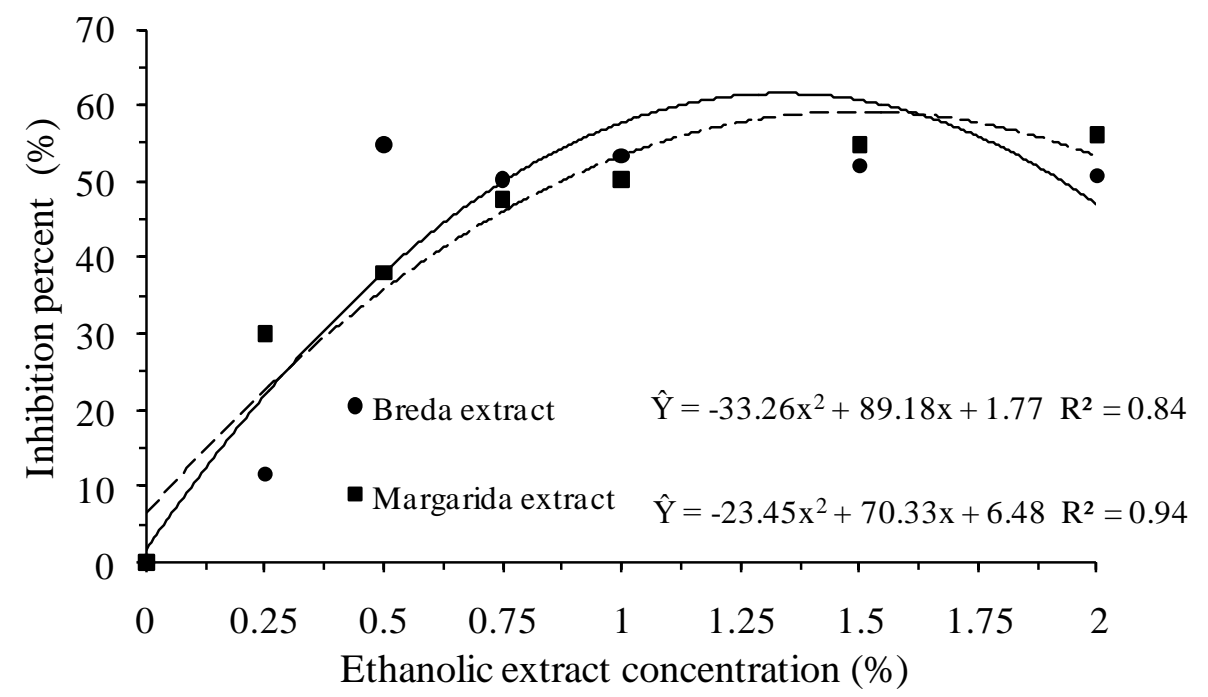

Figure 1. Percentage inhibition of mycelial growth (\%) of Monilinia fructicola under influence of different ethanol extracts at different concentrations at 7 days of incubation.

Both extracts showed a quadratic model that showed the best fit to describe the inhibition percentage as a function of the used concentrations. The 'Breda' extract inhibited $61.55 \%$ of the mycelial growth when adjusted to the concentration of $1.35 \%$, whereas 'Margarida' extract reached $59.25 \%$ of inhibition at concentration of $1.5 \%$.

Similar results were found by Sellamuthu et al. ${ }^{26}$, evaluating the antifungal effect of different concentrations of thyme (Thymus vulgaris L.), peppermint (Mentha piperita L.) and citronella (Cymbopogen nardus) oils in the vapor phase at seven days of incubation. However, the results differed from those found by Flores ${ }^{27}$, in which the inhibition percentage was $78 \%$, using $10 \%$ of canola extract (Brassica napus) in the control of M. fructicola at 8 days of incubation.

The present study showed a difference among avocado cultivars in the pathogen control in the first seven days. A possible explanation for this difference may be related to the contents of antifungal substances present in each cultivar, especially persina. Little is known of the mode of action of 
persin. Most of the speculation on its potential mode of action has focused on the close similarity between persin and the monoglyceride of linoleic acid. Persin may mimic the monoglyceride of linoleic acid in glyceride synthesis ${ }^{28}$. Thus, persin appears to affect tissue cells by interfering with normal lipid biosynthesis ${ }^{29}$.

At the 14th day of evaluation, there was no difference among the used cultivars, only among doses. The quadratic model presented the best fit in relation to the different concentrations (Fig. 2).

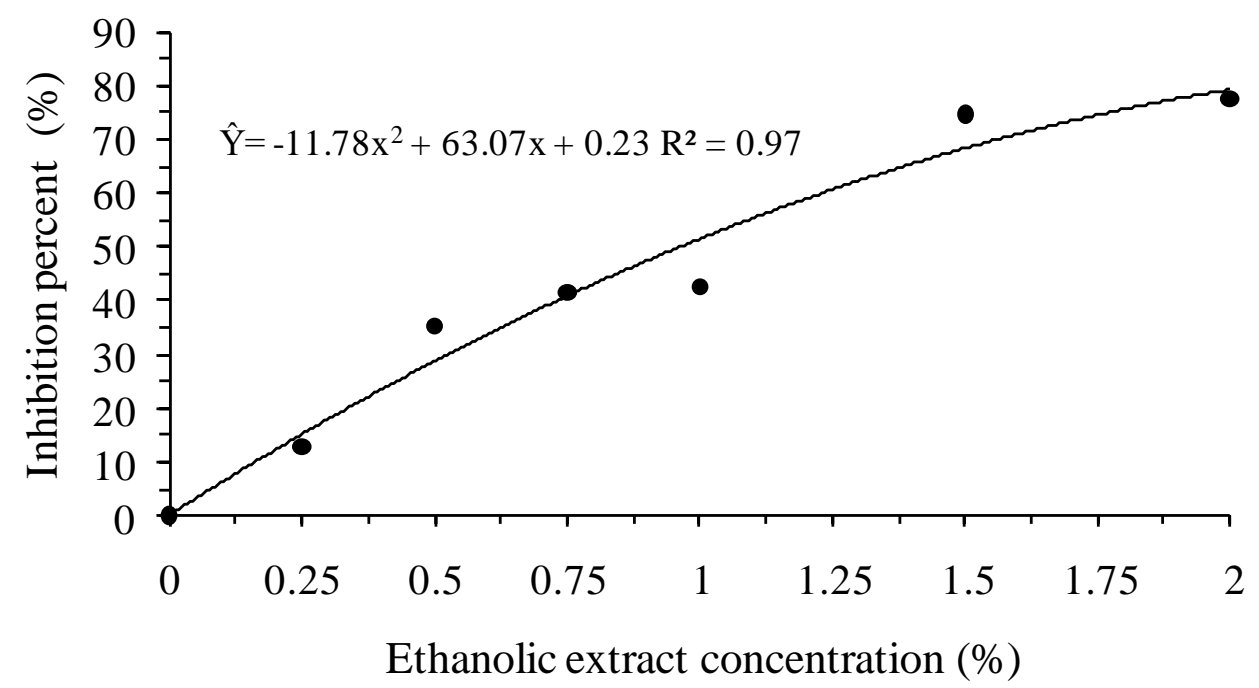

Figure 2. Percentage inhibition of mycelial growth (\%) of Monilinia fructicola under influence of different ethanol extracts at different concentrations at 14 days of incubation.

It is noteworthy the inhibition of mycelial growth of $M$. fructicola, due to the lower concentration of the extract in relation to its absence, with a higher rate observed in the concentration of $2.68 \%$, which showed values of $84.65 \%$. These results corroborate those found by Elshafie et al. ${ }^{30}$ in studies on antifungal activity of the essential oil of constituents Origanum vulgare L. and differ from those found by Pansera et al. ${ }^{24}$ in studies performed with the use of different essential oils, in which essential oils of Cymbopogum citratus and Cinnamomum camphora completely inhibited the mycelial growth of the pathogen after three days at concentrations of $0.05 \%$ and $0.20 \%$ respectively, whereas E. globulus was not able to inhibit mycelial growth at any tested concentration.

There was a trend for linear increase in the inhibition percentage of mycelial growth at 21 days inasmuch as the extract concentration increased, with the highest value (76.4\%) occurring when the concentration of $2.0 \%$ was used (Fig. 3). 


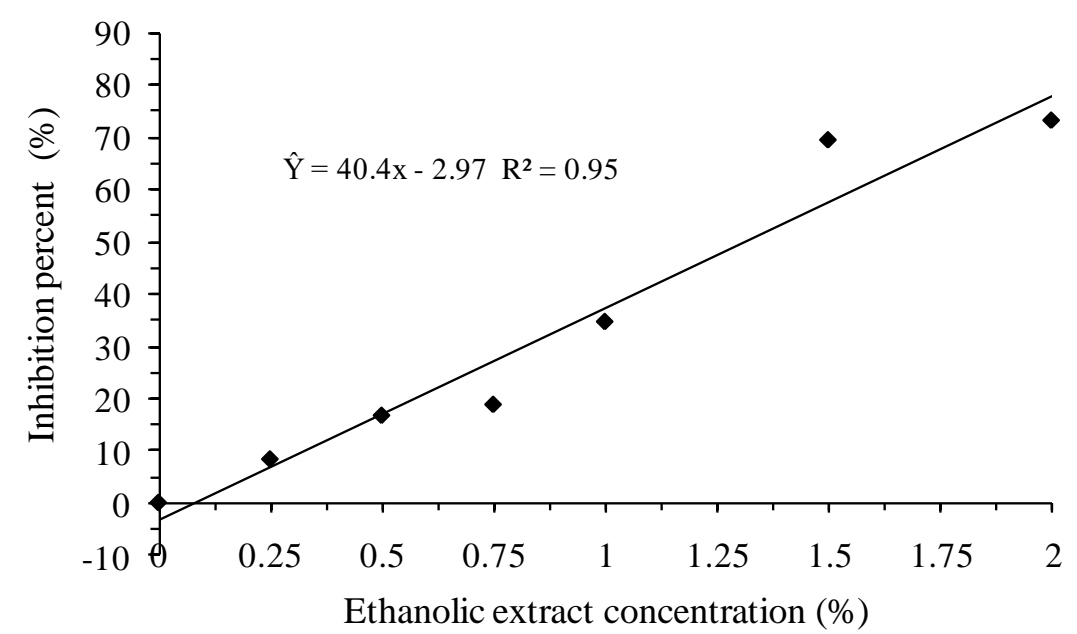

Figure 3. Percentage inhibition of mycelial growth (\%) of Monilinia fructicola under influence of different ethanol extracts at different concentrations at 21 days of incubation.

These results are corroborate with Gomes et $a l .{ }^{31}$, which also observed the trend to increase the percentage of mycelial inhibition with increasing concentration of cinnamon extracts on the pathogen Quambalaria eucalypti. Bernardo et $a l .{ }^{32}$ also found that inasmuch as the concentration of extracts increased, there was an increase in the inhibition percentage, and the carqueja (Baccharis trimera) extract showed the best results on Alternaria alternata, Colletotrichum graminicola, Phytophthora sp., Rhizoctonia solani, and Sclerotinia rolfsii. However, they differed from Nascimento et al. ${ }^{33}$ and Vasconcelos et $a l .{ }^{34}$, where the first author evaluated the antifungal activity of several extracts on the pathogen Cercospora calendulae and found that the confrei (Symphythum officinale L.) extract decreased the inhibition percentage inasmuch as the concentration increased, with rates of $15.03 \%$ in the concentration of $500 \mathrm{mg} \mathrm{L}^{-1}$, reducing to $6.62 \%$ when used $10000 \mathrm{mg} \mathrm{L}^{-1}$; the second author found that crude ethanol extract of cotton (Gossypium arboretum L.) leaves did not show antifungal activity in vitro against the fungus Lasiodiplodia theobromae in the tested concentrations, being possible to detect a growth increase of the fungus at the concentration of $10 \mathrm{mg} \mathrm{mL}^{-1}$.

The results of this study show the efficiency of avocado seed extracts in the inhibition of in vitro mycelial growth of pathogens $C$. gloeosporioides and M. fructicola at low concentrations. This fact can be justified by the presence of acetogenins, since this compound is distributed throughout the plant, although its highest concentration is found in the seeds. This compound comprises a variety of structures, among them the persina, and their mode of action varies accordingly. Generally, they act as potent inhibitors of the respiratory chain, affecting the mitochondrial complex I, causing respiratory chain blocking through the inhibition of the NADH ubiquinone oxidoreductase, an essential enzyme in complex I. This prevents oxidative phosphorylation, directly affecting the electron transport in the cell mitochondria and causing a decrease in ATP levels, leading to apoptosis ${ }^{35,36}$.

\section{CONCLUSIONS}

Ethanol extracts from avocado seeds from cultivars Breda and Margarida were efficient in the in vitro control of Colletotrichum gloeosporioides and Monilinia fructicola, but $C$. gloeosporioides was susceptible only until the 14th day. 
The highest control of $M$. fructicola was detected at 14th day with a dose of $2.68 \%$ and an inhibition rate of $84.65 \%$ when tested for different extract concentrations from both cultivars.

This study demonstrates that subsequent studies should be performed in vivo to confirm the inhibitory effect of these extracts on C. gloeosporioides and $M$. fructicola, by observing the disease symptom in the fruits.

\section{REFERENCES}

1 - Blecher B. 2015. Brasil pode faturar US\$ 750 milhões com exportação de frutas frescas este ano. http://revistagloborural.globo.com/Noticias/Agricultura/Hortifruti/noticia/2015/10/br asil-pode-faturar-us-750-milhoes-com-exportacao-de-frutas-frescas-este-ano.html. (Acessed 14 December 2016).

2 - Bonett LP, Muller GM, Wessling CR, Gamello FD. Extrato etanólico de representantes de cinco famílias de plantas e óleo essencial da família Asteraceae sobre o fungo Colletotrichum gloeosporioides coletados de frutos de mamoeiro (Carica papaya L.). Rev.Bras.de Agroecologia. 2012; 7 (3): 116-125

3 - Oliari ICR, Barcelos RA, Fedrigo K, Garcia C, Marchi T, Botelho RV. Extrato de alga no controle in vitro de Monilinia fructicola. Cadernos de Agroecologia. 2014; 9 (1): 1-5.

4 - Rampersad SN. Molecular and phenotypic characterization of Colletotrichum species associated with Antracnose disease of papaya in Trinidade. Plant Dis. 2011; 95: 1244-1254.

5 - Phoulivong S, Cai L, Chen, H, Mckenzie EH, Abdelsalam K, Chukeatirote E, et al. Colletotrichum gloeosporioides is not a common pathogen on tropical fruits. Fungal Divers. 2010; 44 (1): 33-43.

6 - Garrido LR. Doenças das rosáceas de caroço. Informe Agropecuário. 2016; 37 (291): 75-85.

7 - Ferreira, E M S, Malta, CM, Coelho, CM, Sanzio, R. Substâncias GRAS no controle do crescimento de Colletotrichum gloeosporioides e Fusarium guttiforme in vitro. J. Bioen. Food Sci. 2015; 2 (4): 183-188.

8 - Kefialewa, Y, Avalewb, A. Postharvest biological control of anthracnose (Colletotrichum gloeosporioides) on mango (Mangifera indica). Postharvest Biol. Technol. 2008; 50 (1): 8-10.

9 - Stern JL, Hagerman AE, Steinberg PD, Mason PK. Phlorotannin-protein interactions. J. Chem. Ecol. 1996; 22: 1887-1899. https://doi.org/10.1007/BF02028510

10 - Platt KA, Thomson WW. Idioblast oil cells of avocado: distribution, isolation, ultrastructure, histochemistry, and biochemistry. Int. J. Plant Sci. 1992; 153 (3): 301-310.

11 - Oelrichs PB, Ng JC, Seawright AA, Ward A, Schäffeler L, Macleod JK. Isolation and identification of a compound from avocado (Persea americana) leaves which causes necrosis of the acinar epithelium of the lactating mammary gland and the myocardium. Nat. Toxins. 1995; 3 (5): 344-349.

12 - Rodriguez-Saona C, Millar JG, Trumble JT. Growth inhibitory, insecticidal, and feeding deterrent effects of (12Z, 15Z)-1-acetoxy-2-hydroxy-4-oxo-heneicosa-12, 15-diene, a compound from avocado fruit, to Spodoptera exigua.J. Chem. Ecol. 1997; 23 (7), 1819-1831.

13 - Rodriguez-Saona C, Trumble JT. Biologically active aliphatic acetogenins from specialized idioblast oil cells. Curr. Org. Chem. 2000; 4 (12): 1249-1260.

14 - Koona S, Budida S. Antibacterial Potential of the Extracts of the Leaves of Azadirachta indica Linn. Not. Sci. Biol. 2011; 3 (1): 65-69.

15 - Venturoso LR, Bacchi, LMA, Gavassoni WL, Conus LA, Pontim BCA, Souza FR. Inibição do crescimento in vitro de fitopatógenos sob diferentes concentrações de extratos de plantas medicinais. Arq. Inst. Biol. 2011; 78 (1): 89-95.

16 - Bigaton D, Bacchi LMA, Formagio ASN, Gavassoni WL, Zanella CS. Avaliação da atividade fungicida de extratos e óleos essenciais sobre ferrugem asiática da soja. Rev. Ciênc. Agron. 2013; 44 (4): 757-763. 
17 - Plodpai P, Petcharat V, Chuenchit S, Chakthong S, Joycharat N, Voravuthikunchai SP. Desmos chinensis: a new candidate as natural antifungicide to control rice diseases. Ind. Crops Prod. 2013; 42: 324-331.

18 - Sukorini H, Sangchote S, Khewkhom N. Control of postharvest green mold of citrus fruit with yeasts, medicinal plants, and their combination. Postharvest Biol. Technol. 2013; 79, 24-31. https://doi.org/10.1016/j.postharvbio.2013.01.001

19 - Bona EAM, Silva Pinto FG, Fruet TK, Jorge TCM, Moura AC. Comparação de métodos para avaliação da atividade antimicrobiana e determinação da concentração inibitória mínima (cim) de extratos vegetais aquosos e etanólicos. Arq. Inst. Biol. 2014; 81 (3): 218-225. http://dx.doi.org/10.1590/1808-1657001192012

20 - Venturoso LDR, Bacchi LMA, Gavassoni WL,Conus LA, Pontim BCA, Bergamin AC. Atividade antifúngica de extratos vegetais sobre o desenvolvimento de fitopatógenos. Summa Phytopathol. 2011; 37 (1): 18-23.

21 - Farmacopéia Homeopática Brasileira. São Paulo: Atheneu; 1997.

22 - Edington LV, Khew KL, Barron GL. Fungitoxic spectrum of benzimidazole compounds. Phytopathology. 1971; 61 (1): 42-44.

23 - Ferreira DF. Sisvar: a computer statistical analysis system. Ciênc. agrotec. 2011; 35 (6): 1039-1042.

24 - Pansera MR, Conte RI, e Silva SM, Sartori VC, Silva Ribeiro RT. Strategic control of postharvest decay in peach caused by Monilinia fructicola and Colletotrichum gloeosporioides. Appl. Res. \& Agrotec. 2016; 8 (1): 7-14.

25 - Silva FHA, Do Nascimento JS, De Carvalho Nascimento SR, De Queiroz Ambrósio MM. Aqueous extracts of plants in Colletotrichum gloeosporioides inhibition in vitro and in postharvest guava. Rev. Caatinga. 2014; 27 (1): 93-99.

26 - Sellamuthu PS, Sivakumar D, Soundy P. Antifungal Activity and Chemical Composition of Thyme, Peppermint and Citronella Oils in Vapor Phase against Avocado and Peach Postharvest Pathogens. J. Food Saf. 2013; 33 (1): 86-93.

27 - Flores MF. Extratos vegetais no controle de podridão parda (Monilinia fructicola) em pêssego. 2013. Dissertação de Mestrado. Universidade Tecnológica Federal do Paraná.

28 - Bull, SD, Carman, RM. Synthesis of the Avocado Antifungal,(Z, Z)-2Hydroxy-4-oxohenicosa-12, 15-dien-1-yl Acetate. Aust. J. Chem. 1994; 47(9): 16611672.

29 - Carman, RM, Duffield, AR. The isolation of (R)-2-Hydroxy-4-oxohenicosan-1yl acetate from avocado leaves. Tetrahedron Lett. 1995; 36(12): 2119-2120.

30 - Elshafie HS, Mancini E, Sakr S, De Martino L, Mattia CA, De Feo V, et al. Antifungal Activity of Some Constituents of Origanum vulgare L. Essential Oil Against Postharvest Disease of Peach Fruit. J. Med. Food. 2015; 18 (8): 929-934.

31 - Gomes EMC, Pena RCM, Almeida SSMS. Composição fitoquímica e ação fungicida de extratos brutos de Cinnamomum zeylanicum sobre Quambalaria eucalypti. Biota Amazônia. 2016; 6 (4): 54-58.

32 - Bernardo R, Schwan-Estrada KRF, Stangarlin JR, Oliveira JSB, Cruz MES, Mesquini RM. Atividade fungitóxica in vitro de extratos vegetais sobre o crescimento micelial de fungos fitopatogênicos. Sci. Agrar. Parana. 2015; 14 (2): 89-93.

33 - Nascimento JM, Serra AP, Bachii L, Gavassoni WL, Vieira MC. Inibição do crescimento micelial de Cercospora calendulae Sacc. por extratos de plantas medicinais. Rev. Bras. Plantas Med. 2013; 15 (4): 751-756.

34 - Vasconcelos CC, Isacksson JGL, Silva CB, Cabral NLLA, Almeida SSMS, Pena RCM. Efeito do extrato foliar de Gossypium arboreum L. (algodão) sob o crescimento micelial de Lasiodiplodia theobromae (Pat.) Griffon \& Maubl. Biota Amazônia. 2017; 7 (1): 38-44.

35 - Bermejo A, Figadère B, Zafra-Polo MC, Barrachina I, Estornell E, Cortes D. Acetogenins from Annonaceae: recent progress in isolation, synthesis and mechanisms of action. Nat. Prod. Rep. 2005; 22 (2): 269-303. http://dx.doi.org/10.1039/b500186m.

36 - Rattan, RS. Mechanism of action of insecticidal secondary metabolites of plant $\begin{array}{lll}\text { origin. Crop } & \text { protection, 2010; } & \text { 29(9): }\end{array}$ http://dx.doi.org/10.1016/j.cropro.2010.05.008. 